\title{
Future Trends about Fashion and Technology: A Forward Planning
}

\author{
Manuel Martínez Torán ${ }^{1 *}$, Alicia Bonillo² and Emilio Espíi \\ ${ }^{1}$ Department of Drawing, Universitat Politècnica de València, Spain \\ ${ }^{2}$ Escola d'Art i Superior de Disseny de València, Spain
}

Submission: October 25, 2017; Published: January 12, 2018

*Corresponding author: Manuel Martínez Torán, Department of Drawing, Universitat Politècnica de València, Spain, Email: mmtoran@upv.es

Keywords: Scenario; Prospective; Future; Fashion; Digital; Design; Creation

\section{Perspective}

Fashion is an industry with a economic, environmental and cultural huge impact. Aware the possible future scenarios related to technological change was the aim of our research in 2015-16. We have used the Delphi method in the research, a procedure based on structured questionnaire techniques, that has allowed us to describe conditions that could happen in the fashion industry, by multiple fashion contexts segmentation. The professional field of each profile of a group of international experts, it has been the key element in the textile sector to identify those future trends in the fashion industry. The skills of these international experts in their fields of work are between the communication, the enterprise, the research o the education; and it is these skills that have allowed us to analyze marketing variables like, fast fashion, sustainability or clothing customization in our research. They are experts in textile design, design focused on digital, experimental and technological manufacturing, 3D scanning highly qualified craftsmen, and CAD CAM technicians, as well as entrepreneurs who are committed to making virtual sizes, the tailor-made, or tradesmen that made unique clothing and they prioritize the anthropometric experimental systems over other methods. A system based on fast-fashioned structures, where 'technomode' extends worldwide brings about the continuous innovation in the textile market and the ways that people consume smart clothing [1-3]. The highlighted scenarios are as follows:

\section{Social scenario}

Today the fashion communication is developed on two levels: the street and the catwalks. The digital connection is 'shaking' the current form of dress, it is propagating open inclusive actions about hopes, wishes and needs about the future textile product. The maker culture is based on collaborative and proximity production, and it seeks to share new manufacturing models away from traditional production types Benkler [4]. We talk about a paradigm shift, or to reformulated the sector, where technological change and social progress converge from a technoprogresist position. A new digital consumer arise , based on the roots of a diligent opinion, opinion that mutates within the fashion system, a conscious consumer of the usefulness and validity of these technical interactions $[5,6]$. Our research defines a dynamic 'prosumer', which relies on shared production that it is focused on 'a la carte' future fashion pending changes over the next ten years [7-9].

\section{Economic scenario}

In a deep economic crisis context, the current textile job market, requires a new systems of organization and innovative processes. We highlight the procedures and opportunities from digital collaboration among others. A business strategy widely adopted in the retail trade will be to produce on demand [10-11]. This strategy will help consumers to develop tailored products, participate in the process of co-design and providing value to the service, but the weakness is to take the sizes in. Lindland [12]. Our study refers that the fashion digital consumer will changes the sales operations, by promoting collective intelligence initiatives through social networks. A new economy based on tools, such as crowdfunding, will be encouraged with co-financed clothing or peer to peer production Muntada [13]. This economic scenario confirms a next high digital consumerism, based on social financing and customization (Table 1).

Table 1: Scenarios predicted by context. Professional segment and localization of specialists, who contributed to the Delphi.

\begin{tabular}{|c|c|c|c|}
\hline Context & Social & Economic & Environmental \\
\hline Scenarios & Prosumer & Crowfunding & Intelligent reuse \\
\hline & $\begin{array}{c}\text { Inclusive design Think } \\
\text { thanks }\end{array}$ & $\begin{array}{c}\text { E-commerce Mass } \\
\text { customization }\end{array}$ & $\begin{array}{c}\text { Zero wasteEco-efficiency } \\
\text { Wearables }\end{array}$ \\
\hline
\end{tabular}




\section{Current Trends in Fashion Technology \& Textile Engineering}

\begin{tabular}{|c|c|c|c|c|}
\hline Professionals & $\begin{array}{c}\text { Communication } \\
\text { Research } \\
\text { Academic }\end{array}$ & $\begin{array}{l}\text { Marketing } \\
\text { Fast fashion }\end{array}$ & $\begin{array}{l}\text { Textile design } \\
\text { Sustainability }\end{array}$ & $\begin{array}{c}\text { 3D scanning } \\
\text { CAD-CAM } \\
\text { Fashion technology }\end{array}$ \\
\hline Countries & $\begin{array}{l}\text { Spain } \\
\text { France } \\
\text { Germany }\end{array}$ & $\begin{array}{l}\text { Mexico } \\
\text { Brazil } \\
\text { China }\end{array}$ & $\begin{array}{c}\text { Spain } \\
\text { United Kingdom } \\
\text { Portugal } \\
\text { Morocco } \\
\text { U.S }\end{array}$ & $\begin{array}{c}\text { Spain } \\
\text { Netherlands } \\
\text { Canada } \\
\text { U.S }\end{array}$ \\
\hline
\end{tabular}

\section{Environmental scenario}

According to the experts' answers, a movement in fashion for the benefit of environmental improvement in fashion will revival from textil industry efforts based on 'circular' policies supported by recycling, renewable energy and social justice [14-16]. This movement aims to solve problems such as toxicity, waste of materials, respect for natural resources, and a improvement in resolution of social problems that workers in this industry are continually faced [17-19]. It will often face the negative environmental impacts, that will increase the trademarks transparency policies, creating safe and reusable materials, and the commitment to change the way we do things [20-21]. Collective collaboration will allow to create a positive impact on the fashion industry from the deal of trademark, manufacturer, designer, consumer and/or citizen [15,22].

\section{Technological scenario}

This scenario brings new techniques, utilities and applications in a sector where the fusion between fashion and technology is an unstoppable reality. The experts support the introduction of smart fabrics, and the mixture between technological and traditional disciplines due to wereables [2325]. We are talking about from a generation of new materials, in which nanotechnology will play an essential role determining the properties of tissues, in less than five years [24,26]. Also, the additive manufacturing will allow us to print biodegradable 3D clothing, there will be digital repositories where the manufacturing and downloading the latest in fashion and accessories will be usual (for example the 3D print footwear), a new view of digital and on-line fashion will be provided by the emergence of new materials and the work of designers [27-31].

\section{References}

1. The draping art work of students captured at School of Textile and Design of University of Management and Technology, Lahore, Pakistan.

2. http://historythings.com/happened-ancient-egypt/

3. http://thetorah.com/ancient-egyptian-clothing-real-and-ideal/

4. http://www.fashion-era.com/ancient_costume/ancient-greekfashion-hair.htm

5. https://www.universityoffashion.com/tools/ 